DOI 10.31558/2307-2318.2020.4.28

УДК $(338.47+656)-043.86(477.52 / .6)(045)$

JEL 018

\title{
Горіна Г.О.
}

д.е.н., доцент, завідувач кафедри туризму та країнозавства

Донецький національний університет економіки і торгівлі імені Михайла Туган-Барановського

ORCID 0000-0003-0900-0640

e-mail: gorina@donnuet.edu.ua

\section{ТЕНДЕНЦІЇ РОЗВИТКУ ТРАНСПОРТНОЇ ІНФРАСТРУКТУРИ ДОНЕЦЬКОГО ЕКОНОМІЧНОГО РЕГІОНУ}

У статті на підставі проведення аналізу статистичних показників, що характеризують діяльність підприємств транспорту та транспортної інфраструктури Донецького економічного регіону (довжина шляхів сполучення, кількості автозаправних станцій, динаміка пасажирообігу та перевезень пасажирів за видами транспорту) за 2015-2019 рр. виявлено базові тенденції їх розвитку, а саме: 1) скорочення експлуатаційної довжина залізничних колій загального користування та довжини автомобільних доріг загального користування за Донецьким економічним регіоном в цілому; 2) повільне зменшення кількості автозаправних станцій Донецького економічного регіону; 3) стале зменшення кількості відправлення пасажирів залізничним транспортом загального користування та перевезення пасажирів автомобільним транспортом (автобусами) по Донецького економічного регіону в цілому та окремо по Донецькій та Луганській областям; 4) скорочення пасажирообігу залізничного транспорту загального користування та автомобільного транспорту (автобусів) за Донецьким економічним регіоном.

Ключові слова: засоби транспорту, транспортна інфраструктура, Донецький економічний регіон, автомобільний транспорт, залізничний транспорт.

Рис. - 2, Табл. - 3, Літ. - 12

Постановка проблеми. Транспортна інфраструктура $\epsilon$ важливою складової туристичної індустрії, оскільки засоби транспорту є сполучною ланкою між туристами та подорожуючими 3 різними дестинаціями. Туристична та транспортна індустрії мають взаємний мультиплікативний вплив та взаємозалежну інфраструктуру. 3 одного боку туризм зростає більше швидшими темпами, коли існують розвинені транспортні системи, з іншого - туризм є каталізатором розвитку та підвищення якості туристичної інфраструктури. Інфраструктурний розвиток туристичної та транспортної галузей регіонів України має неоднорідну просторову структуру, оскільки знаходиться під впливом різноманітних факторів, у т.ч. історично-сформованих базових та інноваційних детермінант. Своєчасність та необхідність проведення аналізу розвитку транспортної інфраструктури Донецького економічного регіону та визначенням на цій підставі особливостей та тенденцій розвитку продиктована необхідністю розробки нової парадигми розвитку інфраструктури, яка має створювати стійкі конкурентні переваги та забезпечувати стале зростання регіону. 
Аналіз останніх досліджень і публікацій. Транспортна інфраструктура $\epsilon$ важливою складової інфраструктурного та логістичного розвитку та безпеки держави. Це актуалізує та підтримує сталий інтерес дослідників зазначеної проблематики. Так, Іванов С.В. [1] обгрунтовує прямий зв'язок транспортних витрат 3 витратами інших секторів національної економіки та кореспондування їх з рівнем добробуту населення, визначає сталу тенденцію пріоритетного розвитку наземного транспорту в Україні, зокрема, залізничного та автомобільного. Логутова Т.Г., Полторацький М.М. [2] здійснюють оцінку сучасного стану транспортної інфраструктури України та досліджують понятійний апарат терміну «транспорт», його видів та трактування поняття «єдина транспортна система України» у законодавчих актах та роботах вчених. Шемаєв В.В. [3] розглядає проблему наукового обгрунтування шляхів розвитку транспортної інфраструктури країни 3 урахуванням вимог економічної безпеки держави, визначає загрози та можливості зміцнення економічної безпеки держави під впливом чинників транспортної інфраструктури. Кириленко О.М. [4] досліджує економіко-історичні засади формування транспортної інфраструктури в Україні, джерела формування вантажних потоків на залізничному транспорті. Малиш Н.А., Бондар Н.M. [5] розглядають особливості формування транспортної інфраструктури, визначають іiі сутність та вплив на розвиток країни. Михайличенко Е. [6] здійснює аналіз стратегій розвитку транспортних систем провідних країн світу, на основі яких пропонує стратегічну мету розвитку транспортного сектору України, визначає пріоритети державної політики у сфері транспорту. Незважаючи на наявність різнопланових та грунтовних досліджень транспортної інфраструктури, недослідженими залишаються питання аналізу транспортної інфраструктури Донецького економічного регіону, який дозволить 3 урахуванням регіональних особливостей його розвитку визначити основні тенденції та запропонувати вектори трансформації та сталого зростання економіки регіону.

Постановка завдання. Метою статті є встановлення особливостей та тенденцій розвитку транспортної інфраструктури Донецького економічного регіону на підставі проведення аналізу статистичних показників, що характеризують діяльність підприємств транспорту та транспортної інфраструктури.

Виклад основного матеріалу дослідження. Проведення діагностики сучасного стану та особливостей розвитку транспортної інфраструктури Донецького економічного регіону доцільно розпочати з розгляду класифікації видів транспорту, яка застосовується у міжнародній практиці. У Міжнародних рекомендаціях зі статистики туризму, 2008 р. [7] запропонована класифікація, яка розроблена UNWTO, і вона традиційно використовується в статистиці туризму. Згідно з цією класифікацією усі види транспорту поділяються на три групи: повітряний, водний та сухопутний транспорт (рис. 1). 


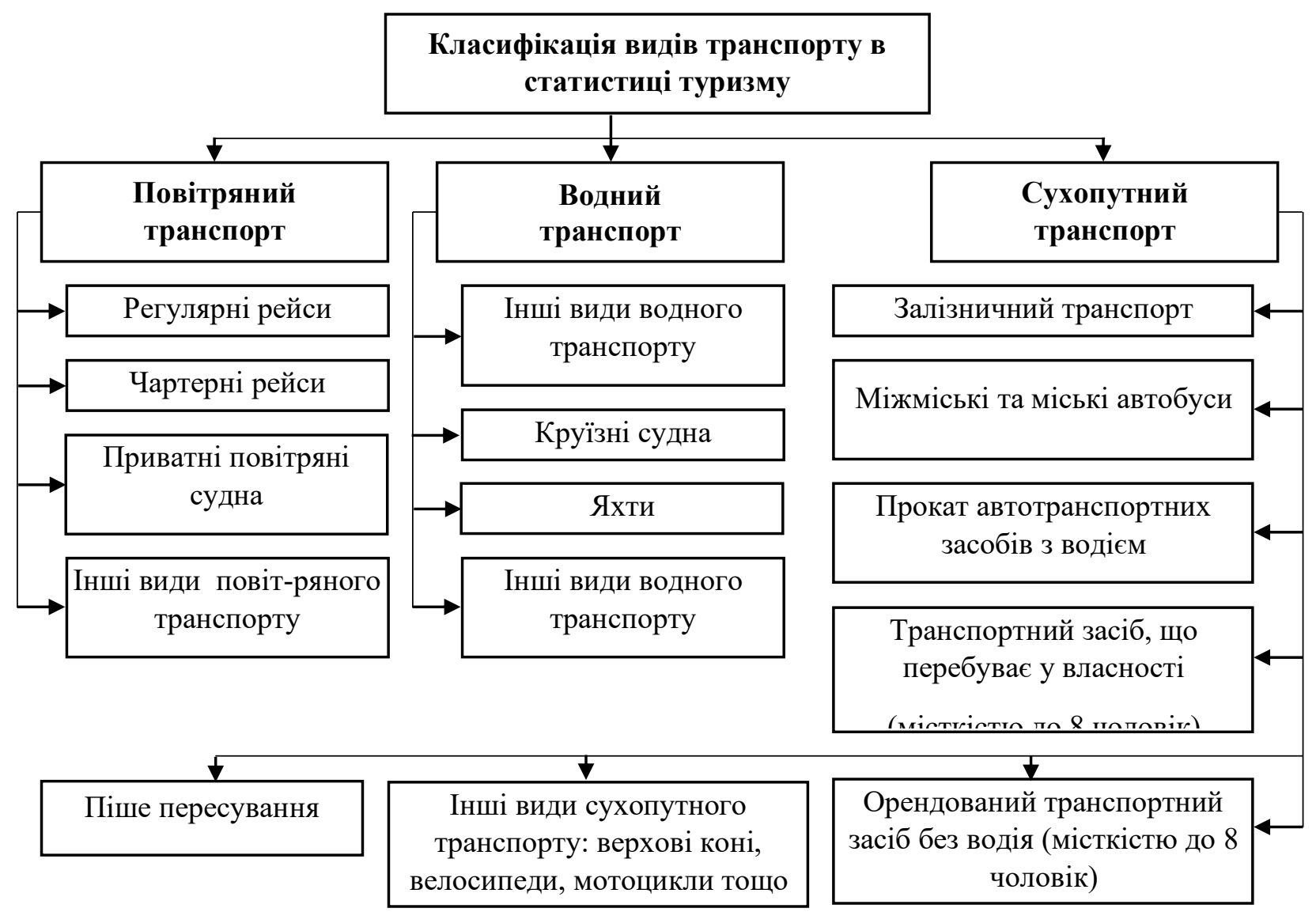

Рис.1. Класифікація видів транспорту в статистиці туризму за Міжнародними рекомендаціями зі статистики туризму, 2008 рік Джерело: складено автором за даними [7]

Державна служба статистики України у статистичному збірнику «Транспорт України» [8] надає статистичні данні 3 трьох основних видів транспорту, а саме: наземний і трубопровідний транспорт, водний транспорт, авіаційний транспорт. Разом 3 тим, данні за регіональною статистикою досить обмежені.

Важливим показником розвитку транспортної інфраструктури України $\epsilon$ довжина шляхів сполучення, а саме експлуатаційна довжина залізничних колій загального користування та довжина автомобільних доріг загального користування.

За аналізований період 2015-2019 рр. експлуатаційна довжина залізничних колій загального користування за Донецьким економічним регіоном скоротилась на 1181 км. $(-44,37 \%)$, за Донецькою областю на 634 км (-40,38\%), за Луганською областю на 547 км (-50,09\%). Довжина автомобільних доріг загального користування за Донецькою областю не змінилась, проте зазнала скорочення за Луганською областю на 1,5 тис. км $(-25,42 \%)$, що спричинило скорочення довжини автомобільних доріг в цілому за Донецьким економічним регіоном на 10,71\% (табл. 1). 
Таблиця 1

Динаміка довжини шляхів сполучення за Донецьким економічним регіоном*,

(2015-2019 pp.)

\begin{tabular}{|l|c|c|c|c|c|c|c|c|}
\hline \multicolumn{1}{|c|}{ Область/регіон } & 2015 & 2016 & 2017 & 2018 & 2019 & $\begin{array}{c}\text { абсолютне } \\
\text { відхилення } \\
\text { до 2015 р. }\end{array}$ & $\begin{array}{c}\text { відносне } \\
\text { дідилення 2015 p. }\end{array}$ \\
\hline \multicolumn{7}{|c}{ Експлуатаційна довжина залізничних колій загального користування, км } \\
\hline Донецька обл. & 1570 & 1570 & 936 & 936 & 936 & -634 & $-40,38$ \\
\hline Луганська обл. & 1092 & 1092 & 544 & 544 & 545 & -547 & $-50,09$ \\
\hline $\begin{array}{l}\text { Донецький } \\
\text { економічний регіон }\end{array}$ & 2662 & 2662 & 1480 & 1480 & 1481 & -1181 & $-44,37$ \\
\hline \multicolumn{7}{|l|}{ Довжина автомобільних доріг загального користування, тис. км. } \\
\hline Донецька обл. & 8,1 & 8,1 & 8,1 & 8,1 & 8,1 & 0 & 0,00 \\
\hline Луганська обл. & 5,9 & 5,9 & 5,9 & 4,4 & 4,4 & $-1,5$ & $-25,42$ \\
\hline $\begin{array}{l}\text { Донецький } \\
\text { економічний регіон }\end{array}$ & 14 & 14 & 14 & 12,5 & 12,5 & $-1,5$ & $-10,71$ \\
\hline
\end{tabular}

* без урахування частини тимчасово окупованих територій у Донецькій та Луганській областях

Джерело: складено та розраховано автором за даними [8]

Ключовим елементом транспортної інфраструктури $\epsilon$ автостанція, яка визначається Законом України «Про автомобільний транспорт» як «споруда або комплекс будівель, споруд, стоянок та під'їздів для прийняття, відправлення, управління рухом автобусів та обслуговування пасажирів» [9]. Згідно даних Міністерства інфраструктури України [10] станом на 2019 р. на території Донецької області працюють 15 автостанцій (Бахмутська АC, Волноваська АC, Гірницька АС, Дружківська АC, Добропільська АC, Краматорська АC, Курахівська АC, Лиманська $\mathrm{AC}$, Мангушська АC, Маріупольська АC, Новодонецька АC, Олександрівська АC, Покровська АC, Святогірська АC, Словянська АC), які знаходять у власності ТОВ «Східні автовокзали». На території Луганської області функціонують 15 автостанцій (Сєвєродонецька АC, Сватівська АC, Троїцька АC, Лисичанська АC-2, Рубіжанська АC, Кремінська АC, Старобільська АC, Новоайдарська $\mathrm{AC}$, Новопсковська $\mathrm{AC}$, Білокуракинська АC, Біловодська АC, Марківська $\mathrm{AC}$, Міловська АC, СтаничноЛуганська АC, Щастинська АC, Лисичанськ АC-1), які знаходяться у власності ТОВ «Регіональне управління автобусних станцій» (ТОВ «РУАС»).

Згідно розробленою Державним комітетом статистики України Інструкцією щодо заповнення форм державних статистичних спостережень стосовно торгової мережі та мережі ресторанного господарства автозаправна станція (АЗС) - «різновид об'єкта напівстаціонарної роздрібної торгівлі 3 продажу пального для автотранспортних засобів з використанням спеціального обладнання, а також супутніх товарів» [11]. Автозаправна станція $\epsilon$ важливим елементом транспортної інфраструктури та підприємством, яке обслуговує подорожуючих та туристів. 32015 р. по 2019 р. кількість автозаправних станцій по Донецькому економічному регіону зменшилась 3633 до 313 одиниць, що склало 3,16\%. Незначне скорочення також зафіксовано у Донецькій області - 6 одиниць $(-2,4 \%)$ та у Луганській області - 14 одиниць (-3,66\%) (рис. 2). 


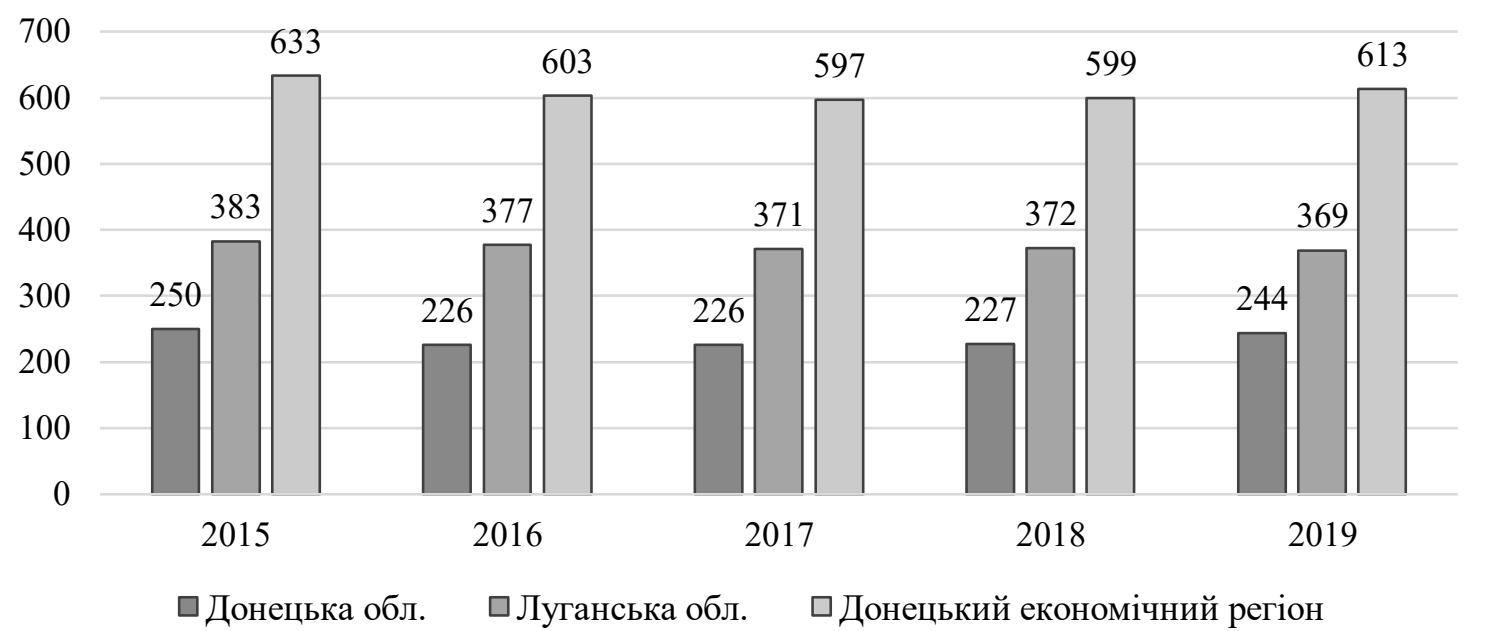

Рис.2. Динаміка кількості автозаправних станцій Донецького економічного регіону, одиниць*

* без урахування частини тимчасово окупованих територій у Донецькій та Луганській областях

Джерело: складено автором за даними [8]

Наступними показниками, які дозволяють оцінити діяльність засобів транспортну $є$ кількість перевезених пасажирів та пасажирообіг. Незважаючи на співзвучність ці показники мають різне смислове наповнення. Так, перевезення пасажирів - це «загальна кількість пасажирів, які транспортовано рухомим складом окремих видів транспорту (автобусами, тролейбусами, трамваями, метрополітенами, залізничними пасажирськими вагонами, річковими та морськими суднами, літаками)» [8]. Тоді як, пасажирообіг - це «загальний обсяг пасажирської роботи, який дорівнює сумі добутків кількості пасажирів (групи пасажирів) на відстань їх перевезення, вимірюється в пасажиро-кілометрах (на морському транспорті - у пасажиро-милях)» $[8]$.

Відправлення пасажирів залізничним транспортом загального користування за досліджуваний період скоротилось по Донецькому економічному регіону на 38,5 млн., що було спричинено відповідним скороченням по Донецькій та Луганській областях на 30,4 млн. (-86,36\%) та 8,1 млн. (-88,04\%) відповідно (табл. 2).

Перевезення пасажирів автомобільним транспортом (автобусами) також зізнало скорочення, а саме на 31,16 \% (38,7 млн.) по Донецькому економічному регіону, на 30,97\% (35,9 млн.) по Донецькій області та на 33,73\% (2,8 млн.) по Луганській області.

Пасажирообіг залізничного транспорту загального користування Донецького економічного регіону забеспечується Регіональною філією «Донецька залізниця» ПАТ «Укрзалізниця» (Філія). До складу Філії входять: 5 локомотивних, 6 вагонних депо, 2 моторвагонних депо; 7 дистанцій колії; 7 дистанцій сигналізації та зв'язку; 5 дистанцій електропостачання; 3 колійних машинних станції; Авдіївський експериментальний завод нестандартного обладнання. Структурні підрозділи підприємства підпорядковуються структурним підрозділам службам Філії. Експлуатаційна довжина головних колій - 1616,7 км, у тому числі експлуатаційна довжина електрифікованих колій - 639 км. Розгорнута довжина головних колій - 2273,1 км. Повна довжина станційних колій - 1283,8 км, повна довжина під’їзних колій - 155,2 км [12]. 
Таблиця 2

Динаміка перевезень пасажирів за видами транспорту за Донецьким економічним регіоном*, (2015-2019 рр.)

\begin{tabular}{|c|l|l|l|l|l|l|c|}
\hline Область/регіон & 2015 & 2016 & 2017 & 2018 & 2019 & $\begin{array}{c}\text { абсолютне } \\
\text { відхилення } \\
\text { до 2015 p. }\end{array}$ & $\begin{array}{c}\text { відносне } \\
\text { відхилення 2015 p. }\end{array}$ \\
\hline
\end{tabular}

Відправлення пасажирів залізничним транспортом загального користування, млн.

\begin{tabular}{|l|c|c|c|c|c|c|c|}
\hline Донецька обл. & 35,2 & 29,5 & 4,3 & 5,2 & 4,8 & $-30,4$ & $-86,36$ \\
\hline Луганська обл. & 9,2 & 12,5 & 1,1 & 1,2 & 1,1 & $-8,1$ & $-88,04$ \\
\hline $\begin{array}{l}\text { Донецький } \\
\text { економічний регіон }\end{array}$ & 44,4 & 42 & 5,4 & 6,4 & 5,9 & $-38,5$ & $-86,71$ \\
\hline \multicolumn{7}{|l|}{ Перевезення пасажирів автомобільним транспортом (автобусами), млн } \\
\hline Донецька обл. & 115,9 & 80,7 & 89,7 & 90,2 & 80 & $-35,9$ & $-30,97$ \\
\hline Луганська обл. & 8,3 & 11,7 & 7,9 & 6,4 & 5,5 & $-2,8$ & $-33,73$ \\
\hline $\begin{array}{l}\text { Донецький } \\
\text { економічний регіон }\end{array}$ & 124,2 & 92,4 & 97,6 & 96,6 & 85,5 & $-38,7$ & $-31,16$ \\
\hline
\end{tabular}

* без урахування частини тимчасово окупованих територій у Донецькій та Луганській областях

Джерело: складено та розраховано автором за даними [8]

За 2015-2019 pp. пасажирообіг залізничного транспорту загального користування зазнав значного скорочення, яке дорівнює $68,42 \%$ (1,3 млрд.пас.км). Відємною тенденцією також характеризується пасажирообіг автомобільного транспорту (автобусів) досліджуваної території. Так, за Донецьким економічним регіоном в цілому пасажирообіг автомобільного транспорту скоротився на $18,41 \%$ (278 млн.пас.км) (табл. 3).

Таблиця 3

Динаміка пасажирообігу за видами транспорту за Донецьким економічним регіоном, (2015-2019 pp.)

\begin{tabular}{|l|c|c|c|c|c|c|c|}
\hline \multicolumn{1}{|c|}{ Область/регіон } & 2015 & 2016 & 2017 & 2018 & 2019 & $\begin{array}{c}\text { абсолютне } \\
\text { відхилення } \\
\text { до 2015 р. }\end{array}$ & $\begin{array}{c}\text { відносне } \\
\text { відилення } 2015 \text { р. }\end{array}$ \\
\hline \multicolumn{7}{|l|}{ Пасажирообіг залізничного транспорту загального користування, млрд.пас.км } \\
\hline Донецька залізниця & 1,9 & 1,9 & 0,6 & 0,6 & 0,6 & $-1,3$ & $-68,42$ \\
\hline $\begin{array}{l}\text { Донецький } \\
\text { економічний регіон }\end{array}$ & 1,9 & 1,9 & 0,6 & 0,6 & 0,6 & $-1,3$ & $-68,42$ \\
\hline \multicolumn{7}{|l|}{ Пасажирообіг автомобільного транспорту (автобусів), млн.пас.км } \\
\hline Донецька обл. & 1330 & 1028 & 1342 & 1510 & 1136 & -194 & $-14,59$ \\
\hline Луганська обл. & 180 & 226 & 222 & 183 & 96 & -84 & $-46,67$ \\
\hline $\begin{array}{l}\text { Донецький } \\
\text { економічний регіон }\end{array}$ & 1510 & 1254 & 1564 & 1693 & 1232 & -278 & $-18,41$ \\
\hline
\end{tabular}

* без урахування частини тимчасово окупованих територій у Донецькій та Луганській областях

Джерело: складено та розраховано автором за даними [8] 
Данні таблиці 3 свідчать, про значне скорочення пасажирообігу автомобільного транспорту (автобусів) у Луганській області - 84 одиниці $(-46,67 \%)$, про помірне зменшення у Донецькій області - 194 одиниці (-14,59\%).

Відсутність зіставних регіональних даних щодо аналізу авіаційної та водної інфраструктури достатньо обмежує повноту проведеного дослідження, разом з тим, забезпечує вектор подальших наукових вишукувань у обраному напряму.

Висновки 3 проведеного дослідження. Здійснення аналізу статистичних показників, що характеризують діяльність підприємств транспорту та транспортної інфраструктури Донецького економічного регіону (довжина шляхів сполучення, кількості автозаправних станцій, динаміка пасажирообігу та перевезень пасажирів за видами транспорту) за 2015-2019 рр. дозволило виявити базові тенденції їх розвитку, а саме: 1) скорочення експлуатаційної довжина залізничних колій загального користування та довжини автомобільних доріг загального користування за Донецьким економічним регіоном в цілому; 2) повільне зменшення кількості автозаправних станцій Донецького економічного регіону; 3) стале зменшення кількості відправлення пасажирів залізничним транспортом загального користування та перевезення пасажирів автомобільним транспортом (автобусами) по Донецького економічного регіону в цілому та окремо по Донецькій та Луганській областям; 4) скорочення пасажирообігу залізничного транспорту загального користування та автомобільного транспорту (автобусів) за Донецьким економічним регіоном. Отримані результати будуть застосовані для розробки стратегічної моделі розвитку транспортної інфраструктури Донецького економічного регіону з урахуванням результатів оптимізації розміщення транспортних хабів.

Перспективним напрямом дослідження є аналіз показників експорту та імпорту транспортних послуг, а також основних показників діяльності підприємств транспортної інфраструктури Донецького економічного регіону.

\section{СПИСОК ВИКОРИСТАНИХ ДЖЕРЕЛ}

1. Іванов С.В. Транспортно-логістичні кластери в контексті розвитку транспортної системи України та окремо взятого економічного району. Економічний вісник Донбасу. 2018. № 1(51). С. 15-22.

2. Логутова Т.Г., Полторацький М.М. Сучасний стан транспортної інфраструктури України. Теоретичні $i$ практичні аспекти економіки та інтелектуальної власності. 2015. Вип. 2(12). Том 2. С. 8-14.

3. Шемаєв В.В. Когнітивний підхід до управління розвитком транспортної інфраструктури України в контексті економічної безпеки держави. Науковий вісник Міжнародного гуманітарного університету. Серія: Економіка і менеджмент. 2017. Вип. 27(1). С. 94-101.

4. Кириленко О.М. Економіко-історичні засади формування транспортної інфраструктури України. Економічна теорія та історія економічної думки. 2016. Вип. № 1(55). С. 7-13.

5. Малиш Н.А., Бондар Н.М. Економічний аналіз транспортної інфраструктури України. Вісник НАДУ при Президентові України. 2016. Вип. 2. С. 50-57.

6. Михайличенко Е. Транспортна стратегія у національних інтересах України. Зовнішня торгівля: економіка, фінанси, право. 2017. № 2. С. 82-94.

7. International Recommendations for Tourism Statistics 2008. URL: http://unstats.un.org/unsd/publication/SeriesM/seriesm_83revle.pdf. 
8. Статистичний збірник «Транспорт України. 2019». Київ: Державна служба статистики України. 2020. 115 с.

9. Про автомобільний транспорт: Закон України від 23 лютого 2006 № 3492-IV / Верховна Рада України. URL: https://zakon.rada.gov.ua/laws/show/2344-14\#Text (дата звернення: 02.12.2020).

10. Міністерство інфраструктури України. URL: https://mtu.gov.ua/ (дата звернення: 03.12.2020).

11. Про затвердження Інструкції щодо заповнення форм державних статистичних спостережень стосовно торгової мережі та мережі ресторанного господарства: Наказ Держкомстату України від 24.10.2005 №327. URL: https://zakon.rada.gov.ua/laws/show/z1350-05\#Техt (дата звернення: 03.12.2020).

12. Акціонерне товариство «Українська залізниця». URL: https://www.uz.gov.ua/ (дата звернення: 03.12.2020).

\section{REFERENCES}

1. Ivanov S.V. (2018). Transportno-lohistychni klastery $\mathrm{v}$ konteksti rozvytku transportnoi systemy Ukrainy ta okremo vziatoho ekonomichnoho raionu. [Transport and logistic clusters in the context of the transport system development of Ukraine and special economic region]. Ekonomichnyi visnyk Donbasu. no. 1(51), pp. 15-22. (in Ukrainian).

2. Lohutova T.H., Poltoratskyi M.M. (2015). Suchasnyi stan transportnoi infrastruktury Ukrainy. [The current state of transport infrastructure in Ukraine]. Theoretical and Practical Aspects of Economics and Intellectual Property. vol. 2(12). pp. 8-14.

3. Lohutova T.H., Poltoratskyi M.M. (2017). Suchasnyi stan transportnoi infrastruktury Ukrainy. [Cognitive approach to managing the development of the transport infrastructure of Ukraine in the context of economic security of the state]. Teoretychni i praktychni aspekty ekonomiky ta intelektualnoi vlasnosti. Vol. 27(1). pp. 94-101.

4. Kyrylenko O.M. (2016). Ekonomiko-istorychni zasady formuvannia transportnoi infrastruktury Ukrainy. [Economic and historic basis for the formation of the transport infrastructure of Ukraine]. Ekonomichna teoriia ta istoriia ekonomichnoi dumky. Vol. 1(55). pp. 7-13.

5. Malysh N.A., Bondar N.M. (2016). Ekonomichnyi analiz transportnoi infrastruktury Ukrainy. [Economic analysis of Ukraine's transport infrastructure]. Visnyk NADU pry Prezydentovi Ukrainy. Vol. 2. pp. 50-57.

6. Mykhailychenko E. (2017). Transportna stratehiia u natsionalnykh interesakh Ukrainy. [Transport strategy in the national interests of Ukraine]. Zovnishnia torhivlia: ekonomika, finansy, pravo. nn. 2. pp. 82-94.

7. International Recommendations for Tourism Statistics 2008. URL: http://unstats.un.org/unsd/publication/SeriesM/seriesm 83revle.pdf.

8. Statistical yearbook «Transport of Ukraine. 2019» (2020). Kyiv: Derzhavna sluzhba statystyky Ukrainy.

9. The Verkhovna Rada of Ukraine (2006), The Law of Ukraine "On road transport", available at: https://zakon.rada.gov.ua/laws/show/2344-14\#Text (Accessed 2 December 2020).

10. Ministry of Infrastructure of Ukraine. URL: https://mtu.gov.ua/ (Accessed 3 December 2020).

11. State Statistics Service of Ukraine (2005), On approval of the Instruction on filling in the forms of state statistical observations regarding the trade network and the restaurant 
network, available at: https://zakon.rada.gov.ua/laws/show/z1350-05\#Text (Accessed 3 December 2020).

12. Joint-stock company "Ukrainian railway". URL: https://www.uz.gov.ua/ (Accessed 3 December 2020).

Горина А.А.

\section{ТЕНДЕНЦИИ РАЗВИТИЯ ТРАНСПОРТНОЙ ИНФРАСТРУКТУРЫ ДОНЕЦКОГО} ЭКОНОМИЧЕСКОГО РЕГИОНА

В статье на основании проведенного анализу статистических показателей, характеризующих деятельность предприятий транспорта и транспортной инфраструктуры Донецкого экономического региона (длина путей сообщения, количество автозаправочных станций, динамика пассажирооборота и перевозок пассажиров по видам транспорта) в 2015-2019 гг. выявлены базовые тенденции их развития, а именно: 1) сокращение эксплуатационной длины железнодорожных путей общего пользования и длины автомобильных дорог общего пользования Донецкого экономического региона в целом; 2) уменьшение количества автозаправочных станций Донецкого экономического региона; 3) устойчивое уменьшение количества отправления пассажиров железнодорожным транспортом общего пользования и перевозки пассажиров автомобильным транспортом (автобусами) в Донецком экономическом регионе в целом и отдельно по Донецкой и Луганской областям; 4) сокращение пассажирооборота железнодорожного транспорта общего пользования и автомобильного транспорта (автобусов) в Донецком экономическом регионе.

Ключевые слова: средства транспорта, транспортная инфраструктура, Донецкий экономический регион, автомобильный транспорт, железнодорожный транспорт.

\section{Gorina G.O.}

\section{DIAGNOSTICS OF REGIONAL HOTEL SERVICES MARKETS INFRASTRUCTURE OF UKRAINE}

In the article on the basis of the analysis of statistical indicators characterizing the activity of the enterprises of transport and transport infrastructure of the Donetsk economic region (length of communication lines, the number of petrol stations, passenger dynamics and passenger modal split) in the 2015-2019 the basic tendencies of their development were revealed, namely: 1) reduction of the operational length of public railways and the length of public highways of the Donetsk economic region; 2) decrease in the number of gas stations in the Donetsk economic region; 3 ) a steady decrease in the number of departures of passengers by public railway transport and the carriage of passengers by road transport (buses) in the Donetsk economic region as a whole and separately in Donetsk and Lugansk regions; 4) reduction of passenger traffic in public railway transport and road transport (buses) in the Donetsk economic region.

Key words: means of transport, transport infrastructure, Donetsk economic region, road transport, railway transport. 